\title{
CPEC and Saudi Arabia: Economic Implication for China and Pakistan
}

\author{
Maira Hilal* \\ M.Phil. Scholar in Asian Studies, Taxila Institute of Asian Civilization, Quaid-i-Azam University, Pakistan
}

*Corresponding author: Maira Hilal, M.Phil. scholar in Asian studies, Taxila

Institute of Asian Civilization, Quaid-i-Azam University, Islamabad Pakistan.

Received Date: November 18, 2019

Published Date: November 27, 2019

\begin{abstract}
China Pakistan Economic Corridor (CPEC) is a part of a strategic geopolitical move that promises not only augment the strategic position of Pakistan but also unleashing socio-economic potentials of Saudi Arabia and China. The research is an effort to highlights the interest of china and Pakistan regarding CPEC. Keeping in view the geo-strategic location of Gawadar port It also provides an insight into the challenges regarding CPEC also it endorses that why Saudi Arabia is keenly interested to join the CPEC and how its involvement boost up its economy? The proposed research is based on descriptive and analytical research methods where primary and secondary both sources are consulted by the researcher to support their argument. So In this way, the results suggest that strategically CPEC would provide a supported system to Saudi Arabia to transform its move into a truly interconnected world. This project has the potential to strengthen the macroeconomic cooperation connectivity peace and growth among different countries through trade and business opportunities which will further generate revenues for Saudi Arabia.
\end{abstract}

Keywords: CPEC, Regional connectivity, Oil trade supremacy, Iran threat, European hegemony

\section{An Overview}

China-Pakistan Economic Corridor (CPEC), is part of the larger Belt and Road Initiative to improve trade, connectivity, cooperation, and communication, between the countries of Eurasia announced by China in 2013 absolutely launched on April 20, 2015 when Pakistani Prime Minister Nawaz Sharif and Chinese president Xi Jinping signed Memorandums of Understanding valued at $\$ 46$ billion. This is eventually a huge investment in any foreign land by China. It is a massive bilateral framework of regional connectivity to improve infrastructure within Pakistan for better trade with China and to further integrate the countries of the region. The goal of CPEC development mega project is both to transform Pakistan's economy by modernizing its networks of railways, highways and energy transportation systems with free and frequent exchanges of growth, enhancing higher volume of flow of trade, to reduce the cost and time of transporting energy and goods such as natural gas to China by circumventing the South China Sea and the Straits of Malacca.

\section{Introduction}

The economic corridor is a long route from Gwadar to Kashgar considered as central to Pak-China relations. The project was the expansion of the international airport and Gwadar deep sea Port. Its target is to fabricate the Gwadar SEZ (Special Economic Zone) that extend over an area of 3,000 acres. The zone was constructed by China and has been functionalized by the end of the year 2017. The proposed infrastructure projects are being financed by heavily subsidized concessionary loans worth $\$ 11$ billion. As part of infrastructure projects, a 1,100-kilometer-long motorway has constructed between the cities of Lahore and Karachi. The KarachiPeshawar railway line has also been upgraded and extended in order to connect to China's Southern Xinjiang Railway in Kashgar. Additionally, a network of pipelines to transport liquefied natural oil and gas plant laid for that $\$ 2.5$ billion has been allocated for pipeline project ruin between Nawab Shah and Gwadar to transport gas from Iran. In future prospect, this project will accommodate industrial units for minerals mines, agriculture, livestock energy, food processing, and agriculture [1].

In the globalized world, China Pakistan Economic Corridor is a journey towards economic regionalization. Itis a bilateral agreement signed between China and Pakistan but now Saudi Arabia as the third "strategic" partner has shown a warm interest toward devoting in multiple CPEC projects. In this regard three 
grant agreements with Pakistan to finance energy and road infrastructure projects are conventional to be assigned during the visit of Saudi Crown Prince Mohammed bin Salman, scheduled in October 2018. The government of Saudi Arabia would invest \$10 billion which may prove an incentive for the hasty completion of multiple projects under CPEC. The country is also seeing at putting money into the gold and RekoDiq copper mine, that like Gwadar (the site of a Chinese-industrial zone and operated port), which is adjacent to the Iranian border and a mere 70 kilometres from Iran's Indian-bolstered port of Chabahar. So, the Investment from worldwide energy like Saudi Aramco oil refinery in Gwadar would circulate other investments and boost port activity also [2].

Despite describing what sort of ties is being initiated among the three parties, we are still unaware of how each party was benefiting and what role Gwadar specifically played to attract those benefits? The main objective of this research is to elaborate Saudi Arabia's extended partnership with China as well as the existing relationship between Pakistan and Saudi Arabia to pursue the reasoning behind its participation in CPEC projects?

\section{Gwadar: a golden sparrow}

For international countries, the location of Gwadar is high sea location, far from the disordered area of the Gulf States and Iraq for any kind of political hindrances during the trade. Gwadar acts as the abbreviated possible route attaching South-West Asia to Central Asia to shift energy and other sorts of natural resources. It has been spotlighting as Pakistan's third naval base after Ormaraand Karachi to function as warm sea water defence for the country. Gwadar is a contender to Iran's Chabahar port, where India will employ a terminal that will be handed down to bypass Pakistan to access central Asia and Afghanistan [3]. It is an end for the China-Pakistan Economic Corridor, which set about in Kashgar, located in China's Xinjiang region. For Pakistan, after Saudi Arabia involvement the provenance of Gwadar leads to the development of Baluchistan and a way of financing the province with infrastructure and extricating most of the natural resources exist in the region. "In light of the deep-rooted instability in the Gulf region, the Gwadar port will provide a proximate and stable point of entry to the Gulf ports. Just $25^{\circ}$ miles from the Straits of Hormuz, by which nearly 40 percent of the world's oil transport, the port is imperatively located to serve as a vital shipping point in the region. The port will provide landlocked Afghanistan, Central Asian republics, and the Chinese Xinjiang region with an approach to the Arabian deep Sea's waters. The port will also facilitate the shifting of Central Asia's huge energy resources to world markets, earning Pakistan significant profits in infiltration fees [4].

\section{Challenges and opportunities for Pakistan}

The world is liquidated from Uni-polarity towards multipolarity and Pakistan appears as a dominant player in this regard due to its economic resourcefulness and geo-strategic location. CPEC is a game-changer for Pakistan. Pakistan needs \$9 billion to run state affairs and it will beat its deadlock with the heavy investment coming from Saudi Arabia and China. Pakistan wants to attract financial and other investment support to tackle a rallying current account deficit caused partly by accelerating oil prices. The project is serving as an extremely attractive destination for local and international both investors. The largest contribution of Saudi Arabia to-wards the development of Pakistan is expected to bring-in consumer montage products, manpower development, finance products, technology transfer, correspondent banking, and international trade. Above all, this massive transfiguration shall be provoked 700,000 jobs for Pakistanis by the year 2030 [5].

Infrastructure development: Pakistan's maritime sector, straddling the North Arabian Sea is bequeathed with an extensive coastline, offering natural harbours and ports to Saudi Arabia. The Gwadar Port and CPEC ensure continuity of supplies in a relatively shorter period, give essential incentives to Pakistan's economy and minimize the cost. The multi-dimensional economic corridor of relatedness is ornamenting Pakistani economy with splendid milestones. Pakistan's economic milieu is ameliorating, and the country is receiving, enjoying perks colossal investment in different sectors of the economy. The Government of Pakistan is expected to establish 27 SEZs under the CPEC. The distribution of SEZs has been made for every province and the figures are as follows: eight in Khyber Pakhtunkhwa, seven in Punjab, seven in Baluchistan, and three in Sindh, whereas the exotic Gilgit- Baltistan and federal territory Islamabad will host one SEZ each [6].

Shipment and labour force: Since a long time, Saudi Arabia and Pakistan have a slant trade balance. In 2016, according to data reported to the United Nations Statistical Division, Saudi Arabia imported \$390 million in commodities and goods from Pakistan, mostly textiles and food, whereas Pakistan imported only $\$ 61.3$ million from Saudi Arabia in return. According to Harvard's Atlas of Economic Complexity, in 2016, Saudi imports from Pakistan included \$26.7 million in beef, \$58 million in rice, and \$21.4 million in lamb, foodstuffs, vegetables and wood constituted more than half of all Pakistani exports to Saudi Arabia, while furniture and textile accounted for another 26 percent. For Pakistan, the economic connectivity of Saudi Arabia is intrinsic to its energy security because Riyadh has consistently accounted that threefourths of Pakistan's crude oil has come from the United Arab Emirates and Saudi Arabia. Hence Pakistan has sought to reduce its perceived over-dependence on Arab Gulf states including Saudi Arabia crude oil, in one instance by drafting a "government-togovernment oil import agreement". But here the key issue still present. Beyond the critical significance of oil, Pakistan heavily relies on remittance payments from Pakistani civilians employed in Saudi Arabia; however, this lifelong trend may be shifting but the 2018 statistics demonstrated that total overseas remittances by Pakistani citizens rise 2.5 percent to $\$ 9.7$ billion in the first half of 2017, and remittances from Saudi Arabia diminish by 7.5 percent to $\$ 2.53$ billion [7].

Trade connectivity: For Pakistan, there is no breakout from geopolitics, even when it comes to issues like trade and connectivity. The biggest challenge is existing attorney war with 
neighbour India and its strong leverage in Afghanistan at the same time currently bettering tough relations with its west. So far Caspian region Russian consortium status quo standby decision on oil pipeline is uptight which extending over Europe and beyond has risk from the construction of a new pipeline as per CPEC. Chinese design in the Indian Ocean is yet another complexity in Pak-Saudi Arabia geo-politics. Not only this, to counter the corridor, 'Chhabra Port' is another lofty design of India with Afghanistan and Iran strategically. Saudi Arabia is going to rotate Gwadar - a leading port in southwestern Baluchistan province -into an oil city, which was part of an accord plan with China. In this way, the domestic appeal of Pakistan will be met if a refinery were to open in Gwadar and it would help Pakistan to recover on import bills and help to tackle the all above problems [8].

\section{Liabilities and assets for China}

From the Chinese perspective, Saudi Arabia has considerable importance for multiple reasons:

a) Saudi's history as a well-grounded partner with all of its customers;

b) the Kingdom is the world's gigantic petroleum exporter, with current crude oil production volume around 12 million barrels per day;

c) the Kingdom has an expensive amount of oil which China desires to run their industries. China realizes that nearly $50 \%$ of the world proven oil reserves are located in the middle east while 17 percent of the world's proven crude oil reserves are located in Saudi Arabia;

d) Saudi Arabia is the comprehensive economy among the Arab countries and the country is also a member of the central bank governors and Group of Twenty Finance Ministers; and

e) Saudi Arabia, the leading member of the Organization of Petroleum Exporting Countries (OPEC), will play progressively imperative role in derive global energy in the future.

Energy transportation: According to Chinese views, energy safety lies at the heart of the symmetrical relationship with Saudi Arabia, as has been the case with many of China's most important strategic ties over the past decade. There are two expositions as far as ties between Saudi Arabia and China is concerned, they are "energy cooperation that has gone away beyond a wholesale relation which depicts that China needs a stable supply while Saudi Arabia needs a stable market for strategic cooperation. For China, Saudi Arabia is a voice of stability and moderation and undoubtedly the isolated foremost principality in the world of energy. It is the driving force that tries to supply the global market with enough oil and bring moderation in prices".

China is the second-considerable consumer of crude oil and its oil imports are supposed to grow from 6 million (bbl. /d) to 13 million (bbl. /d) by 2035. It is the largest exporter to the Middle East, largest trade partner of Saudi Arabia's, the second-biggest player in the Iraqi oil game and the biggest importer of Middle East. China is not substituting to the United States militarily in the short as well as in medium terms, however, the Saudis area attempt to find most of their options unbolted. China, with a sizeable economy of $\$ 21.27$ trillion is searching for longevity in energy imports as it faces multiple challenges on dissimilar economic fronts. Beijing has been progressively looking toward Russia for oil transport, but Saudi Arabia can furnish better standard crude oil at a competitive cost. Following Russia, Saudi Arabia is the second enormous oil exporter and producer (10,050,000 bbl. /d), hence straighten its economy with China by accomplishing Beijing's energy requirements [9].

Geo-strategic and economic landscape: It is important to understand that China's growing relations with the Middle East and other countries are companionship-based relations rather than the formation of an affinity. Through the BRI and China's bilateral relations, China has focused a development-based solution rather than using star power or power politics. China's model has magnetized further interest from Middle Eastern countries and carry them near to China. Saudi Arabia's active attendance in CPEC would provide China an open window of opportunity to achieved easy approach all the way to Eurasia and Africa through Riyadh and Oman [10]. Its participation can embolden other regional countries to participate in this multibillion-dollar project that has the capability to eventually form the geo-strategic and economic landscape of the nation and it will open new vistas of prosperity and development for decades to come. China also aspires to connect with Central Asia via Afghanistan through CPEC. Furthermore, China's active existence in the gulf and Gwadar would make China a "two oceans" power at the same time. Moreover, Saudi Arabia's preparedness to immune global markets in periods of rare density gives the Kingdom a crucial political influence. If Saudi ARAMCO's explosive capacity diminishes, oil prices will become even more evaporative [11].

\section{Conclusion}

'To be concluded my research work it is noteworthy to say that The CPEC being part of the Belt and Road initiative with the scale of its unprecedented ambition entails phenomenal opportunities and unprecedented ambitions, put the KSA China and Pakistan on a well-balanced and sustainable development path. KSA is the outstanding country of GCC, it could be one of the prospects that the other Gulf States, which probably have not any conflict with Pakistan, may fascinate to invest in CPEC protecting their concern whether socio-political and economic. China, Pakistan, and the KSA have muscular socio-economic ties and the triangular interaction so the joint ventures between the three countries may have flashing possibilities for several business arrangements with multiple countries. Moreover, for prospects, it may also prove an inordinate panorama for each country to diversify it excel and economy through the trade of services and establish industries beyond the borders as well as increase collaboration in this endeavour.

\section{Acknowledgement}

None. 


\section{Conflict of interest}

Author has no conflict of interest.

\section{References}

1. A Yasir, R Shahid (2016) CPEC and Pakistani Economy: An Appraisal. Center of excellence for CPEC publications, pp. 1-25.

2. F Shaikh, J Qiang, F Ying (2016) Prospects of Pakistan-China Energy and Economic Corridor. Renewable \& Sustainable Energy Reviews 59: 253263.

3. J Roshan T (2019) Should Saudi Arabia take Interest in the CPEC? Center for Strategic and Contemporary Research.

4. Khalid MA, L Xuemei, B Saranjam (2019) Impact of Transport Cost and Travel Time on Trade under China-Pakistan Economic Corridor (CPEC). Journal of Advance Transportation 1: 1-16.
5. N. Ahsan (2019) CPEC Benefits: Pakistan Offers Investment Opportunities to Saudi Arabia and UAE.

6. (2019) Saudi Vision 2030 and CPEC: Heralding Regional Prosperity.

7. S. Ahmad Khan (2013) Geo-economic Imperatives of Gwadar Sea Port and Kashgar Economic Zone for Pakistan and China. IPRI 13(2): 87-100.

8. S. Jochen (2006) China: A New Actor in the Middle East and North Africa Region? Friedrich-Ebert-Stiftung, Berlin, Germany, pp. 24.

9. Hassan YM (2012) Strategic Importance of Gwadar Port. Journal of Political Studies 19(2): 57-69.

10. Yamada Makio (2011) Gulf-Asia Relations as 'Post-Rentier' Diversification? the Case of the Petrochemical Industry in Saudi Arabia. Journal of Arabian Studies 1(1): 101.

11.Z Anwar (2011) Development of Infrastructural linkages between Pakistan and Central Asia. South Asian Studies: A Research Journal of South Asian Studies 26(1): 103-115. 